\title{
Tradition and transformation in eighteenth-century Europe: Jewish integration in comparative perspective
}

\author{
FRANCESCA BREGOLI ${ }^{\mathrm{a}}$ AND FEDERICA FRANCESCONI ${ }^{\mathrm{b}}$ \\ ${ }^{a}$ Department of History, Queens College of the City University of New York, New York, USA \\ E-mail: francesca.bregoli@qc.cuny.edu \\ ${ }^{b}$ Department of Jewish Studie, Rutgers University, New Brunswick, NJ, USA \\ E-mail: ffrancesconi@jewishstudies.rutgers.edu
}

This issue of Jewish History explores Jewish experiences of integration in eighteenth-century Europe, with a specific focus on Italy, France, Germany, and the Polish-Lithuanian Commonwealth. Through different approaches, which include social and legal history, along with cultural and intellectual analysis, our contributors investigate the various ways that Jewish societies negotiated the interplay between gradual modernization and the maintenance of traditional networks and communal institutions. The investigations include issues of acculturation and legal integration, Jewish economic utility (and its recognition on the part of both Jews and non-Jews), social proximity, religious and lay leadership, class, and gender. The goal is to frame the eighteenth century as a defining age for European Jewry, one that was, to paraphrase Nicholas Terpstra, "simultaneously transformative and reactionary, egalitarian and elitist, [a period] of resistance and of acculturation."1

When analyzing Jewish cultural innovations and the intensity of Jewish contacts with the outside world, contemporary scholars disagree on whether to locate the beginning of modernity in the seventeenth or the eighteenth century. ${ }^{2}$ Recent historiographical works suggest that Jewish modernization was a process rooted in seventeenth-century cultural and social developments, best understood on the basis of prevailing trends during the Ancien Régime. ${ }^{3}$ According to this view, modern Jewry was shaped by a "constellation of processes," to quote Moshe Rosman's apt definition, in which political, socio-cultural, and economic integration were only partial aspects. Additional factors included demographic growth and migrations, nationalism, legal emancipation, secularization, and the erosion of traditional forms of communal and religious authority, all of which led to structural reorganization in modern Jewish communities. ${ }^{4}$ It is undeniable that many of these developments began no later than the seventeenth century. ${ }^{5}$

We are grateful to Omri Elisha and David Myers for thoughtful comments and suggestions on earlier drafts of this introduction. 
Nonetheless, this volume suggests that the eighteenth century, as a period at the intersection of early modern and modern ages in Europe, offers a unique opportunity to explore Jewish developments "toward modernity" while taking into account strong continuities with the previous century. This is not a rehashing of the well-known trope of "continuity and change" in Jewish history. During this period, European Jews obtained concrete social opportunities that had been unavailable in the past. Eighteenth-century sources provide a wealth of evidence of increased contact and proximity between Jews and non-Jews. It is well known that Jews were profoundly affected by the political transformations of European society toward the end of the Ancien Régime. And yet, increasing Jewish openings to the surrounding society coexisted with a variety of formal and informal limitations, both within and without the Jewish community, which restricted (and sometimes thwarted) full integration. The ongoing negotiation between gradual Jewish integration into the larger surroundings and the maintenance of traditional communal institutions, family networks, and individual practices and outlooks emerges as a crucial trait of the eighteenth-century Jewish experience in Europe.

Accordingly, our contributions do not describe spectacular or sudden transformations, nor do they focus only on intellectual elites. The essays rather address gradual processes involving a number of representative European Jewish societies. As we shall see below, scholars have brilliantly demonstrated the effects of radical transformations on eighteenth-century Jewish intellectual elites and popular religious and cultural movements. ${ }^{6}$ However, understanding the significance of modernization for European Jews requires greater attention to the continuities linking processes that preceded what are traditionally regarded as pivotal events in Jewish history (such as the Haskalah or legal equality for Western Jews and the emergence of Hasidism in Eastern Europe) to those that followed them. All of the essays in this volume explore the processual dynamics of modernization for different segments of European Jewry rather than focusing narrowly on "modernity" as a fixed point of arrival. We hope to avoid the common anachronistic tendency to conceive of modernity as a teleological, redemptive act that promised to make amends for the humiliations of the Middle Ages.

The volume's focus on European eighteenth-century contexts is equally deliberate, determined by similarities, as well as comparisons. Instances of nationalism, temporary failures of rabbinic power, and profound acculturation can be located in countless other historical periods and regions, such as in the Roman Empire, post-1096 Ashkenazi societies, and Muslim Spain, while trends similar to those we describe took place in eighteenth-century Atlantic societies and in the mid-nineteenth century in the Ottoman Empire. Nevertheless, we think that it was in eighteenth-century Europe that change manifested itself most clearly and coherently in a reworking of previous political and legal models. Significantly, it was during this time that 
Jews, especially in Italy, moved toward the re-appropriation of their status as "cives" and gradually became full members of secular societies and the civil world. This legal and political integration, along with the cultural challenges it provided, represent a distinctive element among broader transformatory trends (usually subsumed under the term "modernization") that was unique to eighteenth-century Jewish societies in Europe.

Scholarly discourse on Jewish modernization and, accordingly, our understanding of emancipation in Europe, has grown more sophisticated and complex in the past two decades. Early Jewish historiography tended to single out a unique event or moment as a watershed in European Jewish history and to apply a single model to geographically and chronologically diverse Jewish experiences. For instance, Heinrich Graetz (1817-1891) envisioned the intellectual change fostered by the Prussian Haskalah, encapsulated in his opinion by the personality of Moses Mendelssohn, as an almost universal trigger of Jewish modernization, ${ }^{7}$ while Simon Dubnow (1860-1941), opposing Graetz's Germano-centrism, claimed that external political pressure and interference of the state in the wake of the French Revolution destroyed the traditional world of autonomous Jewish communities. ${ }^{8}$

Along similar methodological lines, Jacob Katz's Out of the Ghetto (1973) focused on a linear narrative of Jewish emancipation in Central and Western Europe. ${ }^{9}$ Like Graetz, Katz underscored the self-conscious ideology of the Haskalah as the trigger of a new age in Jewish history, viewing the German example as the model to which all other Jewish societies ultimately conformed. Nevertheless, as early as the 1960s, in the wake of Azriel Shochat's groundbreaking history of seventeenth- and eighteenthcentury German Jews, research already began to pay attention to examples of social integration that took place well before the Haskalah as signs of modernization. ${ }^{10}$ The emphasis on social, unconscious, as opposed to ideologically motivated, conscious change, informed Todd Endelman's The Jews of Georgian England (1979), which in turn influenced scholars in the 1980s and 1990s to explore social and cultural transformations in widely different European areas. ${ }^{11}$ Recent research on England, France, Italy, the Polish-Lithuanian Commonwealth, and the Habsburg Empire has "clearly exposed the inadequacy of the German-Jewish paradigm of emancipationassimilation-reform by giving attention to the wide range of emancipation's legal, social, and political expressions, and its variegated effects on urban and rural populations, class, and gender." 12

While historians increasingly recognize the importance of both social and intellectual aspects of the complex phenomenon of Jewish modernization, contributions over the past twenty years have avoided the tendency of earlier scholarship to describe developments in European Jewry in overarching terms. The questioning of ideologies such as Zionism or assimilationism, 
which guided the work of nineteenth- and twentieth-century Jewish historians and, consequently, the deconstruction of the teleologies engrained in their meta-histories, has led to a greater focus on the national contexts in which Jewish communities encountered pre-emancipatory trends and a renewed appreciation for the plurality of Jewish experience. ${ }^{13}$

It is to Katz's credit that, despite his own aversion to a national understanding of processes of modernization, his edited volume Toward Modernity (1987) represented one of the first examples of the scholarly move toward a greater emphasis on Jewish diversity. ${ }^{14}$ This trend matured in the 1990s, with the appearance of numerous works that highlighted differences and variations in Jewish experience as opposed to similarities, favoring individual and local histories over those of influential personalities and grand teleology. The decade seemed to be marked by the emergence of a consensus about the existence of multiple Jewish "paths to modernity." the 1990s paid increasing attention to gender, family, and the experience of women in relation to the challenges of modern Jewish life. ${ }^{16}$

In the past ten years, the field has grown increasingly complex, as nuanced studies have highlighted the differences between Sephardi and Ashkenazi communities living in Western and Eastern Europe. ${ }^{17}$ Among many important recent contributions, the work of Gershon Hundert should be especially noted for its radical emphasis on regional diversity. Hundert argues that eighteenth-century Poland-Lithuania, which comprised eighty percent of the world Jewish population, cannot be compared with the small Jewish minorities living in Central and Western Europe, because it exhibited none of the traits that historians traditionally see as markers of Jewish modernization, such as gradual integration into the larger society and the adoption of a more universal and less particularistic worldview. Polish Jewry thus emerges as an alternative model, leading Hundert to reformulate the very concept of modernity by challenging its supposed uniformity. ${ }^{18}$

While drawing inspiration from studies that underscore the plurality of experiences across regional and national contexts and upholding the critique of grand teleology, our volume builds on the idea that there is room for comparative analysis of transnational patterns of Jewish modernization. ${ }^{19}$ This was the basis for a panel at the $39^{\text {th }}$ Annual Conference of the Association for Jewish Studies, held in Toronto, in December 2007, which was the starting point for this special volume of Jewish History. ${ }^{20}$ The AJS session addressed processes of Jewish integration in Europe in the last decades of the eighteenth century, with particular attention to comparisons between extant historiographical models. Since a wealth of new research in the past twenty years has accounted for distinct movements and trends in various contexts, our goal was to create a dialogue with the fragmented and regionalistic views of pre-emancipatory processes among different Jewries during the eighteenth 
century with an eye toward assessing whether our discussions might lead to some generalizable patterns. As the panel expanded into a volume, we invited a number of colleagues to bring their expertise to bear on these issues. In the following pages, we present briefly the content of each paper, suggest ways the individual essays are inter-connected, and discuss some of the common themes that emerge from the ensemble.

David Sorkin's paper compares legal changes in the Jewish condition in several early modern European countries, taking issue with the so-called "East-West divide," a concept based on the assumption that emancipatory developments were absent in Eastern Europe, while a progressive march toward emancipation took place in the west. Sorkin argues that this oft-repeated historiographical polarization obfuscates the facts of Jewish legal and political status. Rather, "the developments that historians have tended to treat as 'forerunners' or 'harbingers' of emancipation exclusively in the West had unmistakable counterparts or equivalents in the East." Between 1600 and 1750, local rulers granted some Jewish communities in Italy (in the port-cities of Ancona, before ghettoization, Venice, and Livorno), northern Europe, and Poland-Lithuania generous privileges because of their perceived economic utility. In the course of the early modern period, Jews in Western and Eastern Europe came to acquire a new status of parity, although they did not enjoy political participation. In Italy and Poland-Lithuania Jews benefited from what Sorkin sees as "corporate parity" (defined as "parity or near parity in privileges"), while they enjoyed de jure parity in municipal law in the Dutch Republic and de facto civic parity in England. Jewish communities in the Holy Roman Empire, conversely, received no such freedoms. While they enjoyed a considerable degree of "juridical parity," it was mostly individuals, and not entire communities, who received privileges. On this ground, Sorkin argues that the development of corporate or civic parity, which took place between 1600 and 1750 for both Western and Eastern European Jews, did not occur for Jewish communities in Central Europe.

A relative degree of acculturation and various forms of social integration were integral to Ashkenazi life, even well before the modern times. The papers by Guesnet and Berkovitz offer two perspectives on the legal integration of Ashkenazi communities from the point of view of early modern Poland-Lithuania and eighteenth-century Metz, in Alsace. Guesnet presents a study of little-researched formal agreements (known in Polish as ugody or kontrakty) between representatives of the Jewish community and Christian burghers from 1595 to 1785 . Since they were often geared toward civic obligations and economic opportunities, the ugody were most likely important tools to secure and maintain peaceful relations between different communities. In these agreements, which were voluntary and mutual, the Jewish community was recognized as an equal partner in the contract. Guesnet notes 
that "the process of contracting in early modern Poland [...] gave the Jewish community the status of a legally enabled entity" and constituted a foundation for successful negotiations between Jews and non-Jews. Analysis of the ugody sheds light on the history of Polish Jewish communities in connection with the German territories to which most Polish Jewry could trace its origins. Guesnet suggests that new legal practices emphasizing mutual obligations for both the Christian and the Jewish communities first appeared in Regensburg in the late fifteenth century and were later transmitted eastward as Ashkenazi emigrants fled from persecution. The crucial difference between the German and Polish examples was the contractual nature of the ugody. The development of this legal tool thus elucidates the emergence of what Guesnet calls the "contractual character" of early modern Polish-Jewish relations, ${ }^{21}$ and it emphasizes the improvements in legal status that Ashkenazi Jews experienced when they moved to Poland-Lithuania from the West.

Based on the records of the eighteenth-century Metz rabbinic court (bet din), Berkovitz's paper takes issue with notions that Ashkenazi Jews remained culturally distinct from the outside world until their ultimate "encounter with modernity." True, Alsatian Jews did not become embedded into the fabric of French society. However, integration can be understood as a "process of conforming to prevailing systems of justice, which in the modern state constituted a significant form of attachment to the larger society." The preference given to eighteenth-century Jewish legal sources is meaningful: it was then that "communal legislation no longer drew its authority-whether fictive or real-from the Jewish religious tradition but from an implied social contract that identified the common welfare as its central goal." The Metz records show the large extent to which Jewish legal discourse conformed to French technical legal language, the bet din's awareness of the prevailing French judicial system, its collaboration with French civil courts (best seen in the case of female legal guardians), and the legal awareness of Metz Jews in navigating Jewish and French jurisdictions. As Berkovitz argues, "the integration of Jews into a unified legal system was not synonymous with civilpolitical equality, nor did it confer freedom from prejudice. Rather, the realm of law offered Jews a context, a framework, out of which emerged rules of engagement between the Jewish minority and the surrounding society and culture."

Traditional histories of Jewish integration have often ignored the condition of Jewish women. Carlebach's essay on eighteenth-century Altona challenges the predominant male narrative, showing that overlooked subjects, such as Jewish domestic service, can offer a new perspective on the social proximity between Jews and Christians in Central Europe. Studying maidservants and the difficult status they had within early modern Ashkenazi communities debunks a vision of the Jewish family "built upon the foundation of the virtuous and modest Jewish woman of valor who supported her 
family." In fact, female domestic service was a crucial concern of Ashkenazi kehillot, as Jewish maidservants who crossed the boundaries and roles prescribed by the community "disturbed the moral equilibrium of the family and the home." Drawing from community records and the diary of a local sexton (shammash), the essay shows that the treatment of maidservants blurred differences between Jews and Christians. Not only did Jewish and Christian maidservants and householders display similar behaviors, but similarities can also be detected between the decisions of the Jewish court and those of Christian magistrates with regard to eighteenth-century Altona. The precarious position of unmarried maidservants in Altona, as well as the ambiguous status of fatherless children, allows Carlebach to claim that the categories of class and gender may cut across the boundaries of religion and culture. Indeed, "regardless of religion, the men in power judged Christian and Jewish maidservants in exactly the same way."

It is noteworthy that both Carlebach and Berkovitz emphasize the legal conforming of Jewish and non-Jewish courts, particularly when it came to the treatment of women and orphans. Additionally, Carlebach's paper, with its emphasis on social proximity between Jews and non-Jews, provides an apt link between the first section of the volume and the final two essays, which concentrate on socially integrated and eminently acculturated, though politically disenfranchised, communities: the Jews of eighteenth-century Italy.

Bregoli's essay examines the distinct ways in which the Jewish condition was perceived in the port city of Livorno in the late eighteenth century. Contrary to received wisdom, Bregoli argues that the privileged status of certain mercantile Jewish communities may have been a force for conservatism and not necessarily a catalyst of emancipation. Based on literary and governmental sources, Livorno offers an alternative model of integration to the better-known Prussian and French cases. Given that the Tuscan government and intellectual elite did not consider the useful Livornese minority in need either "of being improved" or better "integrated into society," the classic Enlightenment critiques of Jewish society and the calls for Jewish regeneration typical of the Haskalah were not applicable to this port city. However, the notion of economic utility that defined Livornese Jewry during the Ancien Régime did not bring about greater civil rights for individual Jews, nor did it lead to a smoother progress of emancipation. While the Livornese were acculturated Jews who enjoyed privileges on the grounds of their economic utility, similarly to other commercially useful Jewish communities living in Mediterranean cities or the Atlantic seaboard (often called "port Jews"), their mercantile status did not promote their transition from civil inclusion to political emancipation. Ironically, it turns out, privilege and economic usefulness contributed to the arrested political integration of Livornese Jewry in the 1780s compared to developments in all other Tuscan Jewish communities. 
Francesconi's essay concentrates on the late eighteenth-century Jewish ghetto society of Modena and its progress toward emancipation by focusing on the first steps taken by its leader, merchant Moisè Formiggini, in the arena of Italian political life. Delivering a speech in front of the "new" government of Modena after Napoleon's conquest, in October 1796, Formiggini advocated for full political rights for Jews. Even though Modenese Jews such as Formiggini were not unprepared to deal with the novel freedom brought by Napoleon's armies, their path toward emancipation was neither simple nor straightforward. Francesconi underscores that "officially, in Modena, there was no Jewish question, no public debate, no requests by individual Jews to vote or to sit on civic committees" until the arrival of Napoleon. The Este Dukes granted the Jewish elite extensive liberties as merchants, but refused to give them civil rights of any kind. Formiggini was well aware of this contradiction. A close analysis of his speech shows that he drew largely from celebrated Jewish apologetic works extolling Jewish commercial utility and entrepreneurial savvy. Unlike some of his predecessors, Formiggini did not dwell on the concept of Jewish improvement or regeneration. Rather, seeing himself as part of an informal "body of merchants," he asked that Jews be recognized as "active citizens," a notion derived from French revolutionary discourse, which included "the responsibility of voting, the ability to hold public office, and access to university education and the liberal professions," demonstrating clear awareness of the legal rights obtained by the Jews in 1791.

A variety of common themes emerge from the volume's contributions, such as the extent to which eighteenth-century Jews were able to rely on legal discourse and tools shared with non-Jews, even in the absence of full social integration. Be it the contractual nature of the ugody of Poland-Lithuania explored by Guesnet or the technical terms of the Metz bet din influenced by French language and custom investigated by Berkovitz, eighteenth-century Jewish individuals and communities demonstrated highly developed skills in navigating various jurisdictions. The fact that they were able to do so despite their lack of social integration is a valuable insight into the mechanisms of Jewish cultural adaptation that deserves further study. While historians are paying increasing attention to the fact that many early modern Jews in Europe and the Ottoman Empire relied on non-Jewish courts despite rabbinic injunctions to the contrary, further research on Jewish law in the seventeenth and eighteenth centuries could focus on the ability of Jewish individuals and communities to negotiate between competing legal systems, on the adoption and adaptation of non-Jewish juridical practices within the framework of halakhah, and on the confrontation between the Jews and the "secularized" state with its inclusive, uniform legal system. ${ }^{22}$

Yet another theme running through the volume is the need to explore connections between gender and class among Jews, as we are often in the dark 
about what went on between Jewish women and men within the walls of houses, synagogues, and tribunals. ${ }^{23}$ By entering into the rabbinical court of Metz and the communal meeting hall of Altona, Berkovitz and Carlebach clarify the historiographical picture. The difference between lower and middle-class Jewish women stands out. We see that Jewish female servants were viewed as mere passive objects of sexual exploitation or male conservatism (they were often defined as harlots), while middle-class Jewish widows mediated between civil and rabbinical courts and ameliorated the community's aggressive posture toward women. Further research on Jewish female agency in eighteenth-century Europe will have to focus not only on strategies of negotiation and socio-cultural survival employed by women within the Jewish minority, but also on their ability to navigate everyday life and social dynamics in the larger society of eighteenth-century Europe.

Although Italian Jews were better placed to meet the challenges of integration than other eighteenth-century Jewish communities, the examples examined by Bregoli and Francesconi-the communities of Livorno and Modena-show that progress toward emancipation was neither simple nor straightforward. True, the long and detailed Italian travelogue of Giuseppe Gorani (1740-1819), a philosophe and supporter of Jewish integration, described only the Jewish communities of Livorno and Modena as examples of Jewish cultural advancement and economic integration under relatively enlightened rulers. ${ }^{24}$ This notwithstanding, however, the facts of eighteenthcentury Livorno and Modena reveal a greater complexity. Both in Livorno and in Modena, the discourse of "Jewish improvement" prevalent among Ashkenazi communities across the Alps was absent, while an optimistic belief in commerce as an equalizing force seems to have been widespread among the Jewish intellectual elite and Christian observers sympathetic to the Jews. The emergence of similar dynamics in two important Italian communities, in spite of different status and living conditions, allows us to consider Italy alongside other European Jewish "paths toward modernity."

In the past cultural historians have viewed the Italian Renaissance as a forerunner of the modern age, given the level of acculturation among Italian Jews and their interactions with the majority. ${ }^{25}$ Based on the belief that the roots of modernity in Italy had already emerged in the seventeenth century, if not earlier, and that Jewish acculturation was a fait accompli, ${ }^{26}$ the processes of Italian Jewish integration are often neglected by modern Jewish historians. ${ }^{27}$ By contrast, Bregoli's and Francesconi's essays show that a high level of acculturation and social integration did not lead to political and civil inclusion in any simple or linear way, and they suggest that clear-cut classifications should be avoided. It is our hope that the questions raised and the suggestions offered in this volume will inspire further research to gain a clearer understanding of the role of Italian communities in European Jewish modernization. 
Finally, building on Sorkin's suggestion that a new legal status defined as "corporate" or "civic" parity developed in the seventeenth and early eighteenth centuries among Jews living in Western and Eastern Europe, to the exclusion of the Holy Roman Empire, it remains to be seen whether this novel legal condition affected later processes of integration and whether the privileges enjoyed by Jewish communities in Italy, Holland, England and Poland-Lithuania translated into rights or greater freedoms in the second half of the eighteenth century and in the course of the nineteenth, as the "Jewish question" became the subject of public debate.

Our ultimate goal was to investigate the circumstances of Jewish integration, as well as to underscore the existence of transregional pre-emancipatory trends. We hope that this collection of essays will foster new studies on experiences of Jewish integration in the eighteenth century based on a threepronged approach: attention to common patterns across regional and national contexts, while keeping in mind the remarkable diversity in Jewish experiences; recognition of the importance of gradual processes, as opposed to radical or sudden transformations, to understand major transitions in Jewish history; and emphasis on the dynamic interplay of tradition and transformation in determining events that we later imagine as great leaps forward, while, at the same time, avoiding the fallacy of a teleological narrative.

\section{Notes}

1. Nicholas Terpstra, "De-Institutionalizing Confraternity Studies: Fraternalism and Social Capital in Cross-Cultural Contexts," in Christopher Black and Pamela Gravestock, eds., Early Modern Confraternities in Europe and the Americas: International and Interdisciplinary Perspectives (Aldershot, 2006), pp. 264-283: 277. The original context for Terpstra's definition is early modern fraternalism.

2. For a classic discussion of periodization in Jewish history see Michael Meyer, "When does the Modern Period of Jewish History Begin?" in Judaism 23 (1975), pp. 329-338.

3. See Yosef Kaplan, An Alternative Path to Modernity. The Sephardi Diaspora in Western Europe (Leiden, 2000), Jay Berkovitz, Rites and Passages: The Beginnings of Modern Jewish Culture in France, 1650-1860 (Philadelphia, 2004), and most recently David B. Ruderman, Early Modern Jewry. A New Cultural History (Princeton, 2010).

4. Moshe Rosman, How Jewish is Jewish History? (Oxford, 2007), p. 63.

5. See among others, Salo W. Baron, Social and Religious History of the Jews (New York, 1937), 3 vols., vol. 2, pp. 205-210 and vol. 3, p. 139, note 13; Yosef Hayim Yerushalmi, From Spanish Court to Italian Ghetto. Isaac Cardoso: A Study in Seventeenth Century Marranism and Jewish Apologetic (New York, 1971), p. 44; Gershom Scholem, The Messianic Idea in Judaism and Other Essays in Jewish Spirituality (New York, 1971), pp. 140-141; Samuel Ettinger, "The Beginnings of the Change in the Attitude of European Society toward Jews," in Scripta Hierosolymitana 7 (1961), pp. 193-219; Kaplan, An Alternative Path to Modernity, pp. 1-28. 
6. David Sorkin, The Transformation of German Jewry (1740-1820) (Oxford, 1987); Shmuel Feiner, The Jewish Enlightenment (Philadelphia, 2004); Murray (Moshe) Rosman, Founder of Hasidism: A Quest for the Historical Ba' al Shem Tov (Berkeley and Los Angeles, CA, 1996).

7. Heinrich Graetz, The Structure of Jewish History (New York, 1975), pp. 37, 41, 117-124.

8. Simon Dubnow, "The Sociological View of Jewish History," in Koppel Pinson, Nationalism and History (Philadelphia, 1958), pp. 336-353.

9. Jacob Katz, Out of the Ghetto. The Social Background of Jewish Emancipation, 17701870 (Cambridge MA, 1973), p. 3: “... emancipation in its wider sense occurred more or less simultaneously ... [and] followed a similar, if not identical, course."

10. Azriel Shochat, Im hilufe ha-tekufot (Jerusalem, 1960).

11. Todd Endelman, The Jews of Georgian England, 1714-1830. Tradition and Change in a Liberal Society (Philadelphia, 1979).

12. Berkovitz, Rites and Passages, p. 2. For examples of this trend, see David Fishman, Russia's First Modern Jews: the Jews of Shklov (New York, 1995); Paula Hyman, The Emancipation of the Jews of Alsace. Acculturation and Tradition in the Nineteenth Century (New Haven, 1991); Murray Jay (Moshe) Rosman, The Lord's Jews: Magnate-Jewish Relations in the Polish-Lithuanian Commonwealth during the Eighteenth Century (Cambridge, MA, 1990); Marsha Rozenblit, The Jews of Vienna, 1867-1914: Assimilation and Community (Albany, 1983); Steven Zipperstein, The Jews of Odessa: A Cultural History, 1794-1881 (Stanford, 1985).

13. For a summary of the state of the field on Jewish modernization see Ruderman, Early Modern Jewry, pp. 207-226 and Rosman, How Jewish, pp. 56-81.

14. Jacob Katz, ed., Toward Modernity. The European Jewish Model (New Brunswick, 1987).

15. Frances Malino and David Sorkin, eds., From East and West: Jews in a Changing Europe, 1750-1870 (Oxford, 1990); Jonathan Frankel and Steven Zipperstein, eds. Assimilation and Community. The Jews in Nineteenth-Century Europe (Cambridge, 1992); Pierre Birnbaum and Ira Katznelson, eds., Paths of Emancipation: Jews, States, and Citizenship (Princeton, 1995).

16. Marion Kaplan, The Making of the Jewish Middle Class: Women, Family and Identity in Imperial Germany (New York, 1994), and Paula Hyman, Gender and Assimilation in Modern Jewish History: Roles and Representations of Women (Seattle, 1995). More recently see Chae Ran Freeze, Jewish Marriage and Divorce in Imperial Russia (Waltham, 2001); Iris Parush, Reading Jewish Women. Marginality and Modernization in NineteenthCentury Eastern European Jewish Society (Waltham, 2004).

17. Berkovitz, Rites and Passages; Lois Dubin, The Port Jews of Habsburg Trieste (Stanford, 1999); Kaplan, An Alternative Path to Modernity; David Sorkin, "The Port Jew: Notes toward a Social Type," in Jewish Social Studies 50 (1999), pp. 87-97.

18. Gershon Hundert, Jews in Poland-Lithuania in the Eighteenth-century: A Genealogy of Modernity (Berkeley and Los Angeles, 2004), pp. 1-4.

19. In the 1970 s, younger historians wary of essentializing generalizations started challenging grand master narratives and increasingly avoided sweeping surveys of Jewish history, favoring local, more narrowly focused case studies. This trend has seemingly been reversed in recent years, as Jonathan Israel and David Ruderman have suggested new ways to conceptualize the beginning and end of the early modern period for European Jews from the respective vantage points of economic and cultural history. Despite the important differences in the ways these historians framed their response to the question of periodization, both Israel and Ruderman advocate the possibility of once again conceptualizing the Jewish experience from a transnational perspective: see Jonathan Israel, European Jewry in the Age of Mercantilism (1550-1570) (London, 1998); Ruderman, Early Modern Jewry. 
20. The original panelists for the session, chaired by Lois Dubin, were Jay Berkovitz, Francesca Bregoli, and Federica Francesconi.

21. François Guesnet, "Politik der Vormoderne-Shtadlanut am Vorabend der polnischen Teilungen," in Simon Dubnow Institute Yearbook 1 (2002), pp. 235-255.

22. On the Papal State and the ius commune in the eighteenth-century see Kenneth Stow, "Jewish Pre-Emancipation: Ius Commune, the Roman Comunita, and Marriage in the Early Modern Papal State," in Elisheva Baumgarten, Menahem Ben Sasson, Amnon RazKrakotzkin and Roni Weinstein eds., Festschrift in Honor of Robert Bonfil, (Jerusalem, 2010) and previously, in Stow, Jewish Life in Early Modern Rome: Challenge, Conversion, and Private Life (Aldershot, 2007), pp. 1-24.

23. Notable exceptions are Chava Weissler, Voices of the Matriarchs: Listening to the Prayers of Early Modern Jewish Women (Boston, 1998) and Ada Rapoport-Albert, "On the Position of Women in Sabbatianism," in Rachel Elior ed., The Sabbatian Movement and Its Aftermath: Messianism, Sabbatianism, and Frankism (Hebrew) (Jerusalem, 2001), pp. 143327, forthcoming in an English expanded edition in 2011. See also Federica Francesconi, "Confraternal Community as a Vehicle for Jewish Female Agency in Eighteenth-Century Italy," in Nicholas Terpstra ed., Brotherhood and Boundaries in the Early Modern World (Turnout, forthcoming).

24. Joseph Gorani, Memoires secrets et critiques des cours, des gouvernemens, et des moeurs des principaux etats de l'Italie (London, 1794), 3 vols., vol. 3, pp. 121-127, 204-205.

25. Baron, Social and Religious History, vol. 2, p. 164.

26. For a recent discussion of these themes see David Myers, "Introduction," in David Myers, et al. eds., Acculturation and its Discontents. The Italian Jewish Experience between Exclusion and Inclusion (Toronto, 2008), pp. 3-15.

27. For an overview, see Francesca Bregoli, "Jewish Modernity in Eighteenth-Century Italy. A Historiographical Survey” in Simon Dubnow Institute Yearbook 6 (2007), pp. 67-78. 